\title{
LATE ROMAN D. A MATTER OF OPEN(ING) OR CLOSED HORIZONS?
}

\section{JEROEN POBLOME* and NALAN FIRAT*}

\author{
* Sagalassos Archaeological Research Project, \\ Katholieke Universiteit Leuven, Blijde Inkomststraat 21/3314, 3000 Leuven, Belgium \\ <jeroen.poblome@arts.kuleuven.be> \\ $<$ nalan.firat@gmail.com>
}

In this paper we argue for reconsidering and grouping regional late Roman table ware typologies in the study region of southern Anatolia and Cyprus. Under the common denominator of Late Roman D (LRD), it is proposed to group product lines such as Cypriot red slip ware (CRSW), Sagalassos red slip ware (SRSW) and other recently discovered lines of table ware production in southern Asia Minor. The argumentation builds on published evidence concerning fabric classification, archaeometrical research on clay raw materials and typological comparisons. A broader typological taxonomy is proposed that could lead to important lines of research with respect to the interpretation of regional typologies within their ancient contexts.

KEYWORDS: LATE ROMAN D, CYPRIOT RED SLIP WARE, SAGALASSOS RED SLIP WARE, KOINÈ, FACIÈS GÉOGRAPHIQUE

In 1999, the corpus of Sagalassos red slip ware (SRSW) was published (Poblome 1999). Even if this piece of traditional typo-chronological research and the more interdisciplinary approach toward, for instance, the study of production organisation at Sagalassos (Poblome 2006; Degryse and Poblome 2008) has been well received by peers, the most appreciated comraderie of the latter, however, could never undo one of the most genuine problems of SRSW: its state of (splendid) isolation. Recent work on Cypriot Red Slip Ware (CRSW), on the one hand, and continued excavation and survey fieldwork in south-western Asia Minor, on the other hand, could mean an end to this condition. This paper should be read as a plea to stop investigating matters in isolation, and consider both SRSW and CRSW, as well as other lines of pottery production in southwestern Asia Minor, as part of a broader socio-cultural and socio-economic common language or koinè of pottery production, which is best covered by a very old flag - that of Late Roman D (Waagé 1948).

To be clear, our plea does not assert that there may be no such "thing" as CRSW. Although its production centre(s) are still extant, it is our honest opinion that this gap in our knowledge has much to do with the generally mediocre attention of Classical Archaeology to all things pottery. Yet, the scores of scholars who have in the mean time worked with and published CRSW are not likely to be mistaken in the identification of the fabric and its forms, despite the fact that both aspects leave a margin for interpretation.

Our argumentation actually has more to do with avoiding that the history of identification and comparison of CRSW to the other wares close our eyes and minds to the potential of research ("first come, first served"). Indeed, new potential for the study of CRSW is gradually being unlocked in the wider study region by new evidence, and, in our opinion, hints at the existence of, at least in late Roman times, a range of regional production centres involved in the making of a cohesive and consistent range of table ware types and forms, very much in parallel to the 'faciès géographique' of African red slip ware(s) (ARSW) (Bonifay 2004) or the less well studied Late Roman C wares.

\section{CRSW fabric classification and identification}

Based on a short review of the fabric classification and description of CRSW, it seems fair to conclude that the ware can be macroscopically recognized, classified and therefore separated from other contemporary types of table ware. Therefore, the classification of CRSW as a fabric holds, as it does for its counterparts. Two problems remain, however: whether or not CRSW is the best label for this fabric and whether or not we need to associate a single source with this fabric.

The label CRSW was coined by J.W. Hayes (1972) in his Late Roman Pottery. The latter connoisseur equalled his CRSW to the earlier classification by F.O. Waagé (1948) of this fabric as Late Roman D ware (LRD). In the words of Frederick Waagé (1948: 52) LRD “... is rather common, but not as much so as Late $C$, and is marked rather by a consistency of shape than of fabric. It varies from a brown body and red-brown varnish to an almost purplish-brown body and varnish; the body is always hard and pure, without the grainy quality of Late $C$, and the varnish seldom has any gloss." No suggestion of provenance was made, nor did Waagé do so for his Late Roman E ware, which was also grouped under CRSW by John Hayes (1972: 371). Waagé's (1948: 52) fabric description of the latter reads as follows: "The red-brown body is dense, pure and very hard and often burns dark, with an almost purplish hue; the dark red varnish, also purplish when particularly dark, always has a metallic sheen.". 
John Hayes (1972: 371) not only joined Waagé's LRD and LRE wares under the heading of CRSW; he also introduced a proposed provenance: "The exact source of the ware is unknown, but it was in all probability made somewhere in Cyprus, where examples are commonest.". According to Hayes (1972: 371), the fabric of CRSW “... is consistently very fine and smooth, with no grains visible and breaks cleanly, even when ill-fired. The only obvious impurities are occasional lumps of lime, often quite large, which tend to rupture the surface... The degree of firing and colour of the fabric vary enormously, the latter ranging from near-yellow through various shades of orange, brown and red to deep maroon, purple or sepia; a pinkish or maroon tint is commonest... A thin slip coating is applied to the whole of the surface... This slip, which is of similar nature to the body-clay, and tends to merge with it, has a matt appearance on the more poorly fired pieces, but acquires a metallic lustre when hard-fired; it is generally a shade darker than the clay beneath... Some early pieces have a rather thicker slip with a fine lustrous appearance identical with that of the earlier Cypriot sigillata ware; these constitute Waagé 's Late E ware. Otherwise the fabric remains remarkably consistent throughout its history, with the exception of a bad phase around the middle of the sixth century.".

In his Supplement to Late Roman Pottery, John Hayes (1980: 62) did not add to his fabric description, but restated that: "The exact source of this ware has not yet come to light, but a Cypriot origin remains the most likely.". Twenty years later he appears to have some doubts as to the provenance of CRSW: "In fact we still do not know where this was made, any more than we know the source of its early forerunner, the so-called Cypriot sigillata. The frequency with which both wares occur on the Egyptian, Palestinian and Syrian coasts might lead one to different conclusions, but I frankly doubt any such origins. Perhaps the ware was traded from some point even beyond Cyprus - poorly studied Pamphylia remains a slender possibility. (Hayes 2001: 277)". According to Hayes' footnote 26, this change may have come about based on information supplied by the authors of this contribution.

In the most detailed study to date on CRSW, Henryk Meyza (2007: 13) builds on Hayes' conclusion in stating that for both Cypriot sigillata and CRSW "their exact place of production is unknown and their very identity as Cypriot wares ... is questioned by some scholars, including the author of their names, J.W. Hayes. In opinion of the present author it is justified to name them Cypriot, but possibly Cyprus was not the only place of origin of those wares.". Henryk Meyza (2007: 18) also maintains Hayes' earlier fabric description, adding important details: "Cypriot Red Slip ware is a pottery made of clays with relatively low content of calcium in the matrix, but quite numerous lime impurities and relatively little purified artificially. It contains particles of calcareous inclusions, which occasionally erupt after firing and pit the surface, but there is no temper or igneous inclusions... Macroscopically the fabric varies in colour, hardness and porosity, but compared to other fine wares it can normally be easily discerned from all other ceramics save earlier Cypriot Sigillata and sometimes Pontic Sigillatal Red Slip.". Strikingly enough, after this last sentence, Henryk Meyza goes on to describe in which different ways the ware was macroscopically classified at a range of published sites, based on absence/presence criteria of a metallic sheen of the slip, a more or less sandy fabric, or micaceous inclusions.

From this overview of research on CRSW, it is clear that its fabric can be fairly easily macroscopically separated from its main counterparts in the eastern Mediterranean, being African red slip ware (ARSW) and Late Roman C (LRC). Visual distinction being only one part of defining fabrics, the main descriptions of CRSW's fabric cited in full do not seem to guarantee internal cohesion. Waagé says it in so many words, whereas the following descriptions potentially group/hide various types and origins of clays for body and slip, clay preparation methods and firing techniques. At the very least, the various CRSW fabric classifications from literature collected by Henryk Meyza (2007: 18) seem to suggest as much. In the most general examples, the available fabric descriptions for CRSW are fairly generic, practically paralleling the fabric definition of other wares, such as SRSW (Poblome 1999: 27) It might be worth noting that Sagalassos is situated rather close to Pamphylia (a possible production area proposed by Hayes). To make this sound less absurd, we should add that the fabric descriptions of the recently attested Kibyra red slip ware (Uygun and Dökü 2008: 135-136) is also quite similar. The same goes for the so-called derivative CRSW fabric attested at Pisidian Pednelissos (Kenkel 2007), where recently another potters' quarter was identified (Vandeput and Köse 2008: 33). In addition to these newly discovered Pisidian pottery production centres, "imitation CRSWs" have also been described at Pamphylian Perge (Firat 1999; 2000) and Rough Cilician Anemurium (Williams 1989: 50-51).

In our opinion, the state of the field concerning the classification of CRSW leads us to suggest that we are actually dealing with a group of fabrics, or an "umbrella" ware, which has classificatory value with other major contemporary table wares, but is in need of further detailed description underneath the "umbrella." Efforts such as 'The National Roman Fabric Reference Collection' (Tomber and Dore 1998) could point the way to refining these issues, as well as websites (Keay and Williams 2005). Perhaps archaeometry can provide further insights as to whether this preliminary conclusion has consequences in terms of provenancing (and therefore labelling) the range within this "umbrella" ware.

\section{Archaeometry}

The archaeometrical fingerprinting of SRSW (Degryse and Poblome 2008), including the identification of the source of its clay raw materials, was completed fairly soon after the discovery of its Potters' Quarter in the eastern suburbia 
of Sagalassos. Unfortunately, such is not the case for most other major late Roman red slipped wares. Be this as it may be, CRSW has been archaeometrically described, and provenanced to western Cyprus, despite the fact that no production centre(s) have been archaeologically attested.

Applying neutron activation analysis at the Missouri University Research Reactor (MURR) on extensive collections of both sherds and clays, Gomez et al. (2002: 32) recently concluded for CRSW that, "a regionalized pattern of resource exploitation is suggested by the distribution of the limestone outcrops that support remnant clay-rich soil in western Cyprus. Either processing prior to firing or alteration during burial could have induced the compositional differences between the Roman fine wares and the extant clays, but they are most likely attributable to hydrochemical processes.". The latter processes prevent exact source location for the clay raw materials, as these blur the matching between the finished products and the original clays. The clay raw materials are considered to be "chromic luvisols (terra rossas) developed on Mioceneage reefal limestones that outcrop around the periphery of the Troodos Massif (Gomez et al. 2002: 27)" with best matching for "three samples of the residual clay-rich soils in the region to the north of Paphos (Gomez et al. 2002: 31)". Interestingly, the same clays were the basis of a contemporary tile industry establishing a concentration of artisanal activity in the sphere of attraction around Nea Paphos (Lund 1997). Tile making was most probably a rural undertaking, whilst producing table wares is mostly a suburban activity. Rural potting of table wares is not to be excluded in the Roman world, but even in that case, the technology of making and firing tiles and table vessels is very different and would require different workshop infrastructure.

This research firmly concludes that CRSW was made on Cyprus and continued the tradition of Cypriot sigillata, but as archaeometrical research is necessarily based on sampling, more work is required to link these results with the macroscopic classification of the group of associated fabrics mentioned earlier. XRF-analyses by Gerwulf Schneider (2000) and the technological study by Malgorzata Daszkiewicz (1997) on CRSW, suggested that various CRSW workshops were using a geochemically homogeneous clay raw material. In future studies, it is also advisable to include samples of exported CRSW from sites within the traditional distribution pattern of the ware to check whether the same consistency of composition holds true or whether the attested macroscopic fabric variation could imply other, yet unknown sources. One such CRSWlike fabric was very well attested at Pamphylian Perge, for which the archaeometrical research resulted in the identification of a previously unknown production centre in western Asia Minor, which used clays weathered from a volcanic/plutonic acidic rock (Poblome et al. 2001). Typologically, this yet unlocated production centre was not only involved in the manufacturing of CRSW-like material, but also SRSW-like material, as well as other products well-attested at Hierapolis. To make matters worse, some sherds from Sagalassos which were macroscopically undistinguishable from the standard range of SRSW fabric and types, proved to also originate from this yet unlocated production centre.

In conclusion, the available archaeometrical results have decided on a Cypriot production of CRSW, and have also demonstrated the existence of at least one other production centre making not only similar products from a fabric point of view, but identical CRSW products from a typological point of view (along with other types). Given the cited difficulties of the detailed macroscopic classification of CRSW in literature (mainly outside Cyprus) and the problem of matching archaeometrical results to both the macroscopic classes and the strong typological ties (which we develop below), it seems safer to us, pending further archaeometry, to use a more generic label for most of these wares, especially those found outside Cyprus namely that of LRD. Only in cases where we can firmly associate archaeometry with typological and macroscopic observation can we use specific provenanced labels such as CRSW or SRSW. Kibyra red slip ware and Pednelissos red slip ware will no doubt complicate these matters! In the mean time, the current state of the evidence through the macroscopic and archaeometrical fabric classification of CRSW should leave the option open that other production centres than the Cypriot one(s) provided the market. More generic labelling, such as LRD, replicates the umbrella state of affairs of this fabric and avoids potential problems in uniquely associating distribution patterns with CRSW and recognizes that other production centres possibly located outside of Cyprus, in southwestern Anatolia or anywhere else within the general distribution pattern of LRD, may have played a role too. Therefore, as a next step, preferably in tandem with more archaeometry, more attention should be paid to establishing links and differences among the typological repertoires of established and presumed production centres.

\section{Typology}

Apart from the above, another good reason to start contemplating the re-introduction of the label LRD can be found in the study of the typological repertoire of the ware. As usual in the late Roman table ware landscape, the introduction of a comprehensive CRSW typology was made by John Hayes (1972: 371-386). He reported "heavy rather crude potting and rough irregular rouletted decoration ... Vessels are mostly thick-walled, and tend to have a poor finish ... The basic vessel forms are few, and are rather less standardized than those of the African wares, with one form shading off into another". Summarizing recent literature on CRSW, Henryk Meyza (2007: 15) concluded along the same line that: "Generally number of forms corresponded to relatively few types proposed by Hayes, though within-type variation was shown to be high.". In the following section, we intend to follow Hayes' classification whilst looking for typological connections from the available literature within the proposed study area. 
Hayes CRSW Form 1 was dated from the late fourth century to about the third-quarter of the fifth century and was proposed as the initial form of CRSW (Hayes 1972: 372-373). Henryk Meyza (2007: 44-49) offers variants for this type and confirmed Hayes' chronology. This first form is actually a good example of how the typology of CRSW also works rather like an "umbrella." The concept of a wide dish with flat base and flaring walls is clear and different from the other CRSW types, as well as the other major types of table ware in the Roman East. In other words, we agree with H. Meyza that inspiration for this type being Hayes ARSW Form 50 is possibly far-fetched, as is the case with Hayes LRC Form 1D, as no other major type of table ware had a similar profile. May we suggest original skeuomorphic inspiration? Internal cohesion of the type, on the other hand, is less straightforward, with differences in the execution of the ring foot, the carination of the wall, the wall thickness and the rim. Within the proposed study area, this form is comparable to (or has as generic prototype with) SRSW types and variants 1C1203 (best fit with the larger, more shallow examples) and occasionally to SRSW 1C60-1 (Poblome 1999: 308-309), which dated from the first to the third century, possibly into the third quarter of the fourth century AD (Poblome et al. 2008). SRSW 1C160-1 similis are perhaps best considered differently from this Form 1 and classified under another heading. Derivates of this CRSW form are also mentioned for Pednelissos (Kenkel 2007: 135) and Perge (Firat 1999: 40-41). In this context, we wish to question the use of the term 'derivate' or 'imitation' and prefer to use the "umbrella" logic of the CRSW typology to group such similar morphological manifestations under one envelope. This implies that the same form concept was executed contemporaneously at more than one production centre in the LRD zone, using the various attested fabrics and various attested typological details of the vessels. The history of labelling fabrics and identifying forms should not impose the chronology and the relationship between 'original' (read CRSW) and 'derivate' or 'imitation' (read CRSW-like products), whereas each "envelope-" type forms part of the LRD koinè. In other words, LRD Form 1 contains CRSW Form 1 and other comparable forms from other production centres in the LRD zone. We will use the terms so-called "derivates" and so-called "imitations" below, in order to keep the terminology from the original publication consistent; however, we urge a different perspective toward morphological relationships that may possibly be inspired by a common, non-pottery source, such as silver plate. The use of these terms for material from different sites does not imply provenance from the same production centre or use of the same fabric, and thus, supports the logic of the LRD koinè.

Hayes CRSW Form 2 was dated from around AD 450 to around the middle of the sixth century (Hayes 1972: 375-376) and can be compared to Hayes ARSW Form 84. Henryk Meyza shifted the chronology slightly to between the early fifth century and the middle or the third-quarter of the sixth (Meyza 2007: 51-53; contra: P. Reynolds in this volume). The general shape and decoration on Hayes
CRSW Form 2.2 are very comparable to the late SRSW $1 B 191$ variant (Poblome 1999: 297), which is dated to the first half or third quarter of the fourth century. The rouletted decoration on these vessels could be a skeuomorphic feature imitating the faceting on (precious) metal vessel walls, as could be the general concept of the vessel shape. Like CRSW Form 1 and SRSW 1C120-3, no direct relationship is to be expected between CRSW Form 2 and SRSW 1B191 apart from indicating that there are morphological roots for CRSW in the study region. The fact that a so-called derivate CRSW Form 2 was attested at Perge and Pednelissos in the so-called CRSW fabric (Firat 1999: 43-44; Firat 2000: 35) (Kenkel 2007: 136) indicates further that this type should be considered part of the LRD koinè. A so-called imitation CRSW Form 2 was also registered at Anemurium (Williams 1989: 50).

Hayes CRSW Form 3 was dated between the thirdquarter of the fifth century and the second quarter of the sixth (Hayes 1972: 376). Its shape was a smaller version of CRSW Form 2 and is therefore better compared to SRSW 1B190-1. Henryk Meyza proposed a somewhat longer chronology between the second half of the fifth and the end of the sixth century (Meyza 2007: 53-55). Socalled derivates of this form were attested at Pedneslissos (Kenkel 2007: 136-137).

Hayes CRSW Form 4 was considered rare and possibly datable to the fifth century (Hayes 1972: 376-377). Henryk Meyza opened up the chronology with an end-date in the late sixth or early seventh century (Meyza 2007: 55-56). The type's distinctive morphological feature, a beaded rim, is a skeuomorphic aspect and also features on SRSW 1B233, datable between the fifth and seventh centuries (Poblome 1999: 307). A so-called derivate CRSW shape was noted at Perge (Frrat 1999: 46), and a so-called imitation CRSW Form 4 was catalogued at Anemurium (Williams 1989: 50).

Hayes CRSW Form 5 has been dated to the mid and late sixth century (Hayes 1972: 377). Henryk Meyza considered this type to be less well-defined and proposed a chronology between the early sixth and early seventh century (Meyza 2007: 56-57). Derivates of this form were recognized at Pednelissos (Kenkel 2007: 137).

Hayes CRSW Form 6 was considered rare and possibly dated to the sixth century (Hayes 1972: 377). Henryk Meyza expanded this type and proposed a dating to around the middle of the seventh century (Meyza 2007: 57-58). This shape finds good parallels in SRSW 1 B140 which was datable to the sixth and seventh centuries (Poblome 1999: 305; Poblome et al. 2001: fig. 4, 3). So-called derivate shapes were attested at Perge, in 'CRSW' fabric (Firat 1999: 47-48; Firat 2000, 35-36), as well as at Pednelissos (Kenkel 2007: 137).

Hayes CRSW Form 7 was dated mainly to the secondhalf of the sixth and the early seventh centuries (Hayes 1972: 377-379). Henryk Meyza proposed a date from 
shortly before AD 450 until the early seventh century (Meyza 2007: 58-59). This basin form finds good parallels with SRSW 1F180, datable to the fifth to seventh centuries (Poblome 1999: 310; Poblome et al. 2001: fig. 4, 8). A so-called derivate type was found at Perge (Firat 1999: 50-51), and such so-called derivates were also common at Pednelissos (Kenkel 2007: 137). An 'imitation CRSW Form 7' was identified at Anemurium (Williams 1989: 51).

Hayes CRSW Form 8 was considered rare and possibly dated to the sixth century (Hayes 1972: 379). Henryk Meyza provided more substantial dating evidence to between the fifth and the seventh centuries (Meyza 2007: 60-61). This type finds good parallels in SRSW 1B230231, datable to the sixth and seventh centuries (Poblome 1999: 307; Poblome et al. 2001: fig. 4, 5; Poblome et al. 2005: fig. 2). Derivate forms in so-called CRSW fabric were noted at Perge, whilst the CRSW version of the type was absent (Firat 1999: 51-52; Firat 2000, 35). In turn, the latter were present at Pednelissos, whilst its derivates were more common (Kenkel 2007: 137). At least one sample of this shape from Perge belonged to the unprovenanced LRD fabric (Poblome et al. 2001: fig. 3, 6). A so-called imitation form was also catalogued at Anemurium (Williams 1989: $51)$.

Hayes CRSW Form 9 was dated to the middle of the sixth until the end of the seventh centuries (Hayes 1972: 379382), and Hayes CRSW Form 10 was considered rare and dated to around the middle of the seventh century (Hayes 1972: 382-383). Both shapes are very similar. Therefore, Henryk Meyza proposed a new classification system with variants spanning CRSW Forms 9 and 10, datable to between the middle of the sixth and the seventh centuries (Meyza 2007: 61-72). Comparable dishes to CRSW Forms 9 and 10 were registered at Sagalassos, mainly from the end of the sixth century and onwards (Poblome et al. 2010: fig. 3). Meyza's Form K5 can also be compared to SRSW (Poblome et al. 2001: fig. 4, 9). Derivate shapes for both CRSW types were attested at Perge (F1rat 1999: 54-58; Firat 2000: 36-37) and Pednelissos (Kenkel 2007: 137139).

Hayes CRSW Form 11 was dated to between the middle of the sixth to about the middle of the following century (Hayes 1972: 383). Henryk Meyza proposed a starting date around the middle of the fifth century (Meyza 2007: 72-75). Meyza's CRSW Form 11C is comparable to SRSW 1F180, which is dated to the fifth to seventh centuries (Poblome 1999: 310; Poblome et al. 2001: fig. 4,8 ), whilst other basins found at Sagalassos can also be compared (Poblome et al. 2010: fig. 3).

Hayes CRSW Form 12 was considered rare and dated to about the middle of the seventh century (Hayes 1972: 383-385). Henryk Meyza proposed a longer chronology between the late fourth and the early seventh centuries (Meyza 2007: 75-77). The morphology and decoration find good parallels in SRSW 1A140-3, datable to the second half of the fourth and the seventh centuries. The seventh century version sometimes has handles (Poblome 1999: 304-305; Poblome et al. 2001: fig. 4.1; Poblome et al. 2010: fig. 3).

Although we consider the addition of types by Henryk Meyza to Hayes' CRSW series useful, we would like to plea for an easier labelling system, which can be replicated throughout the LRD zone. Also, some of these additional types are paralleled by other products within the study region.

Meyza CRSW Form H1/3C was dated from the middle of the fourth century until the middle of the fifth (Meyza 2007: 49-50). The type is fairly well defined externally and internally and finds clear parallels in SRSW 1B130, datable between the middle of the fourth into the seventh centuries (Poblome 1999: 305; Poblome et al. 2001: fig. 4, 2). At Sagalassos, this type is very common. Hayes ARSW Forms 50B, 80B and 81B are considered comparanda. A similar shape in an unprovenanced LRD fabric was also attested at Perge (Poblome et al. 2001: fig. 3, 1).

Meyza CRSW Form K1 was dated to 380-450 AD (Meyza 2007: 50-51). The type is fairly well defined externally and internally and finds parallels with SRSW 1B210, datable between the fifth and seventh centuries AD (Poblome 1999: 307; Poblome et al. 2005: fig. 2). Meyza's CRSW Form K1/3, on the other hand, finds parallels with SRSW 1B220, datable between the fifth and seventh centuries. At least one sample of this type from Perge belonged to the unprovenanced LRD fabric (Poblome et al. 2001: fig. 3, 4).

The so-called Well-form (Meyza 2007: 79-80) finds good parallels in SRSW (Poblome et al. 2001: fig. 4, 10 \& 12; Poblome et al. 2005: fig. 2; Poblome et al. 2010: fig. 3), and derivative shapes in 'CRSW' fabric were attested at Perge (Firat 1999: 58-60; Firat 2000, 37-38).

In conclusion, most of the classic CRSW forms can be easily distinguished within the range of products of other major table wares in the Roman East, such as LRC and ARSW. The CRSW range of forms has its own independent morphological logic, tied to its region of production. The new element which this paper aims at introducing is that CRSW does not stand alone in this study region, but that other production centres, such as Pednelissos, Sagalassos and surely other yet undiscovered centres, were involved in producing table wares that followed a similar regional morphological logic. So far, the products of the attested potters' quarter of Kibyra do not feature in this typological discussion, since the available publications consider only late Hellenistic and imperial products (Uygun and Dökü 2008) or late Roman unguentaria (Özdüdoğru et al. 2007). It is striking, however, how various Kibyra shapes find good counterparts in the contemporary SRSW series, possibly indicating that the concept of a common morphological language or koinè of pottery production may also be found in earlier periods. However, this is beyond the scope of this paper. Additionally, in a previous 
paper dealing with a (late sixth/)seventh century ceramic assemblage found at Sagalassos (Poblome et al. 2010), we also included cooking wares, along with table ware, in what we envisaged as the early Byzantine version of exchange patterns of the sort documented by John Lund (1999) in the study region for the period $100 \mathrm{BC}-200 \mathrm{AD}$. John Lund demonstrated, based on mainly ceramological evidence, a sphere of contact between (Rough) Cilicia, western Cyprus, the southern Levant and Egypt, in contrast to another sphere of contact involving eastern Cyprus and the northern Levant. We argued for the extension of this zone of pottery production and distribution in order to include more of southern Anatolia. Importantly, the existence of this 'zone' of pottery production and distribution does not necessarily place Cyprus at the head of contemporary socio-cultural developments: the island, strategically located along various sea routes, could have provided cohesion within the study region.

\section{LRD all the way!}

In our opinion, during the late Roman period the range of products in the study region seems to be clear and typologically cohesive enough to argue for the existence of an LRD common language or koinè, in dialectical relationship with 'faciès géographiques' of pottery production. The latter concept was most usefully introduced by Michel Bonifay (2004) in order to link groupings of typo-chronological and technological details of North African table/cooking/common wares, amphorae and oil lamps to regional zones of production within North Africa that displayed a certain degree of internal cohesion. In linguistic terms, a 'faciès géographique' of pottery production can also be understood in terms of a dialect drawing upon more general language systems or koinè, but creating a recognisable mix of vocabulary, pronunciation and grammar used by a particular group of speakers, who are regionally or socially connected. In other words, ARSW, LRC and LRD can be understood to function as common languages or koinè with dialects or 'faciès géographiques' grouped underneath these headings - such as, in our case, CRSW, SRSW, Pednelissos red slip ware, possibly Kibyra red slip ware and other unprovenanced fabrics.

However, one could argue that LRD, ARSW or LRC, as such, never existed as a koinè, since these were only composed for our modern analytical purposes. In answer to this observation, we could state the obvious that ever since F.O. Waagé's 1948 volume (but possibly in practice earlier), no Roman pottery specialist would confuse the major types of late Roman table ware: ARSW, LRC and LRD are externally too different from one another. Apart from the obvious, this issue also refers to a wider problem (or rather research potential, if you like) in, for instance, the debate on "Romanisation," where both in the post-colonialist and globalizing schools of thought (Hingley 2005; Wallace-Hadrill 2008) the non-existence of a fixed toolkit of 'Roman' material culture, which was to be acquired in order to become 'Roman', has been demonstrated, whereas both schools acknowledge shifts in socio-cultural matrices upon the integration of regions into the Empire. It is exactly this tension between the generic (read 'Roman') and the specific (read 'regional'/'local') aspects of culture which drove the logic of the production and exchange of Roman material culture. In our opinion, this observation implies a challenge for research, with the potential of making our typologies more meaningful in their ancient contexts. Clearly, every community consciously or not was making choices in acquiring material culture. When the community of Sagalassos conceived its pottery industry in mid-Hellenistic times and expanded it in Imperial times (Poblome 2006), they could in theory choose between different socio-cultural koinè and in practice, at least in late Roman times, "joined" the LRD camp. At this point in time, our knowledge of Roman material culture has progressed sufficiently to start mapping the different camps or koinè, but understanding why such socio-cultural affiliations came about and in precisely which configurations will be a most challenging and welcome avenue of interdisciplinary research, especially when broadened to other types of archaeological evidence.

Finally, we should like to tap back into the introduction to this paper, and conclude that the concept of LRD koinè means a sort of 'home-coming' for SRSW, but also potentially for Kibyra and Pednelissos red slip wares, and other production centres in the LRD zone, which had previously been perceived in relative isolation. At least in the case of Sagalassos, we have at our disposal a whole new range of different excavated deposits in order to clarify the chronological development of LRD.

\section{Acknowledgements}

This research was supported by the Belgian Programme on Interuniversity Poles of Attraction (IAP 6/22) and the Research Fund of the K.U.Leuven (BOF-GOA 07/02 - Methusalem 07/01), next to projects G.0788.09 and G.0562.11 of the Fund for Scientific Research, Flanders (FWO).

\section{Bibliography}

Bonifay, M. (2004), Etudes sur la céramique romaine tardive d'Afrique, BAR Int. Ser. 1301, Archaeopress, Oxford.

Daszkiewicz, M. and Schneider, G. (1997), Chemical composition of Cypriot red slip wares from Kourion and Nea Paphos, Polish Archaeology in the Mediterranean VIII, Reports 1996: 139-143.

Degryse, D. and Poblome, J. (2008), Clays for mass production of table and common wares, amphorae and architectural ceramics at Sagalassos, in P. Degryse and M. Waelkens (eds.), Sagalassos VI, Geo- and Bioarchaeology at Sagalassos and in its territory, Leuven University Press, Leuven: 231-254.

Firat, N. (1999), Perge konut alanı keramiği, unpublished Ph.D. thesis, Istanbul University, Istanbul. 
Firat, N. (2000), So-called 'Cypriot red slip ware' from the habitation area of Perge (Pamphylia), in RCRF Acta 36, Rei Cretariae Romanae Fautores, Abingdon: 35-38.

Gomez, B., Neff, H., Rautman, M.L., Vaughan, S.J. and Glascock, M.D. (2002), The source provenance of Bronze Age and Roman pottery from Cyprus, Archaeometry 44: 23-36.

Hayes, J.W. (1972), Late Roman Pottery, The British School at Rome, London.

Hayes, J.W. (1980), Supplement to Late Roman Pottery, The British School at Rome, London.

Hayes, J.W. (2001), Late Roman fine wares and their successors: a Mediterranean Byzantine perspective, in E. Villeneuve and P.M. Watson (eds.), La céramique byzantine et proto-islamique en Syrie-Jordanie, Institut Français d'Archéologie du Proche-Orient, Beirut: 275282.

Hingley, R. (2005), Globalizing Roman culture. Unity, diversity and empire, Routledge, London-New York.

Keay, S. and Williams, D. (eds.) (2005), Roman Amphorae: a digital resource, University of Southampton, http://ads.ahds.ac.uk/catalogue/archive/amphora ahrb 2005/index.cfm

Kenkel, F. (2007), The Cypriot red slip ware and its derivates from Pednelissos in Pisidia, in B. Böhlendorf-Arslan, A.O. Uysal and J. Witte-Orr (eds.), Çanak. Late antique and medieval pottery and tiles in Mediterranean archaeological contexts, Byzas 7, Ege Yayınlar1, Istanbul: 131-146.

Lund, J. (1997), The distribution of Cypriot sigillata as evidence of sea-trade involving Cyprus, in S. Swiny, R.L. Hohfelder and H. Wylde Swiny (eds.), Res Maritimae. Cyprus and the eastern Mediterranean from prehistory to late antiquity, American Schools of Oriental Research Archaeological Reports 4, Scholars Press, Atlanta, GE: 201-216.

Lund, J. (1999), Trade patterns in the Levant from ca. $100 \mathrm{BC}$ to AD 200 as reflected by the distribution of ceramic fine wares in Cyprus, Münstersche Beiträge zur Antiken Handelsgeschichte 18: 1-22.

Meyza, H. (2007), Nea Paphos V, Cypriot Red Slip Ware: studies on a Late Roman Levantine fine ware, Polish Academy of Science, Warsaw.

Özüdoğru, Ş. and Dündar, E. (2007), Kibyra Geç Romaerken Doğu Roma mühürlü Unguentariumları, Olba 15: 145-178.

Poblome, J. (1999), Sagalassos red slip ware. Typology and chronology, Studies in Eastern Mediterranean Archaeology 2, Brepols Publishers, Turnhout.

Poblome J. (2006), Made in Sagalassos. Modelling regional potential and constraints, in S. Menchelli and M. Pasquinucci (eds.), Territorio e produzioni ceramiche: paesaggi, economia e società in età romana, Instrumenta 2, University of Pisa Press, Pisa: 355-363 and 420-421.

Poblome, J., Bes P. and Degryse, P. (2005), The decline and fall of Sagalassos. A ceramic perspective, in $R C R F$ Acta 36, Rei Cretariae Romanae Fautores, Abingdon: 225-230.

Poblome, J., Degryse, P., Cottica D. and Firat, N. (2001), A new early Byzantine production centre in western Asia Minor. A petrographical and geochemical study of red slip ware from Hierapolis, Perge and Sagalassos, in RCRF Acta 37, Rei Cretariae Romanae Fautores, Abingdon: 119-126.

Poblome, J., Corremans, M., Bes, P., Romanus, K. and Degryse, P. (2008), It is never too late... The late Roman initiation of amphora production in the territory of Sagalassos, in I. Delemen, S. Cokay-Kepçe, A. Özdibay and Ö. Turak (eds.), Euergetes. Festschrift für Prof. Dr. Haluk Abbasoglu zum 65. Geburtstag, Suna and Inan Kıraç Research Institute on Mediterranean Civilizations, Antalya: 1001-1012.

Poblome, J., Bes, P., De Cupere, B., Lauwers, V., Romanus, K., Vionis, A.K. and Waelkens, M. (2010), Sic transit gloria mundi. Does it really? Wasting seventh century AD Sagalassos (SW Turkey), in S. Menchelli, S. Santoro, M. Pasquinucci and G. Guiducci (eds.), LRCW 3, Late Roman Coarse Wares, Cooking Wares and Amphorae in the Mediterranean, Archaeology and Archaeometry, Comparison between western and eastern Mediterranean, BAR Int. Series 2185, Archaeopress, Oxford: 791-801.

Tomber, R. and Dore, J. (1998), The national Roman fabric reference collection. A handbook, MOLAS Monograph 2, Museum of London Archaeology Service, London.

Schneider, G. (2000), Chemical and mineralogical studies of late Hellenistic to Byzantine pottery production in the eastern Mediterranean, in RCRF Acta 36, Rei Cretariae Romanae Fautores, Abingdon: 525-536.

Uygun, Ç. and Dökü, E. (2008), Kibyra Yerel kırmızı seramiklerinden örnekler, Adalya 11: 133-163.

Vandeput, L. and Köse, V. (2008), Pisidia survey project 2008: research in the territory of Pednelissos, Anatolian Archaeology 14: 32-33.

Waagé, F.O. (1948), Hellenistic and Roman tableware of North Syria, in F.O. Waagé (ed.), Antioch-on-theOrontes IV, 1, Ceramics and Islamic coins, Princeton University Press, Princeton: 1-60.

Wallace-Hadrill, A. (2008), Rome's cultural revolution, Cambridge University Press, Cambridge.

Williams, C. (1989), Anemurium. The Roman and early Byzantine pottery, Subsidia Mediaevalia 16, Pontifical Institute of Mediaeval Studies, Wetteren. 